\title{
Efektivitas Atraktan Tahu, Oncom dan Kacang Tanah pada Fly Trap dalam Pengendalian Lalat
}

\author{
Annisa Pangestuti Utoyo ${ }^{1}$, Yustini Ardillah ${ }^{1 凶}$
}

${ }^{1}$ Fakultas Kesehatan Masyarakat, Universitas Sriwijaya

\author{
Info Artikel \\ Diterima 03 Juni 2021 \\ Disetujui 26 Juni 2021 \\ Diterbitkan 30 Juni 2021
}

\section{Kata Kunci:}

lalat, atraktan, tahu, oncom, kacang tanah.

\section{e-ISSN:}

2613-9219

\section{Akreditasi Nasional: \\ Sinta 4}

\section{Keywords:}

Flies, atraktant, tofu, oncom, peanut.

\section{$\square^{\square}$ Coresponding author: yustiniardillah@gmail.com}

\begin{abstract}
Abstrak
Latar belakang: Lalat merupakan salah satu vektor penyakit yang perlu diwaspadai dan dapat menyebabkan penyakit infeksi saluran pencernaan. Upaya pengendalian lalat dapat dilakukan mengunakan fly trap sebagai perangkap lalat dan atraktan sebagai zat penariknya. Atraktan yang digunakan adalah tahu, oncom dan kacang tanah. Tujuan: Penelitian ini bertujuan untuk menganalisa perbedaan efektivitas atraktan tahu, oncom dan kacang tanah pada fly trap dalam pengendalian lalat area Pasar Kalirejo, Kabupaten Lampung Tengah. Metode: Penelitian ini menggunakan desain true experiment dengan rancangan posttest control group design. Populasi pada penelitian ini adalah semua jenis lalat yang berada di Pasar Kalirejo. Sampel pada penelitian ini adalah lalat yang tertangkap pada fly trap. Analisis data secara univariat dan bivariat dengan metode One Way Anova untuk data berdistribusi normal dan Kruskal-Wallis untuk data yan berdistribusi tidak normal. Hasil: Penggunakan atraktan kacang tanah mampu menangkap lalat dengan rata-rata lalat tertangkap sebanyak 21,11 ekor, 15,39 ekor pada atraktan oncom, 4,89 pada atraktan tahu (p value < 0,05). Kondisi suhu saat penelitian sebesar $26^{\circ} \mathrm{C}$ sampai $27^{\circ} \mathrm{C}$ dengan presentase kelembaban sebesar $68 \%$ sampai $70 \%$. Kesimpulan: penelitian ini adalah terdapat perbedaan jumlah rata-rata lalat yang tertangkap pada penggunaan atraktan tahu, oncom dan kacang tanah.
\end{abstract}

\begin{abstract}
Background: Flies are one of the vectors of disease that need to be watched out for and can cause digestive tract infections. Efforts to control flies can be carried out using fly traps as fly traps and attractants as attractants. The attractants used were tofu, oncom and peanuts. Objective: This study aims to analyze the differences in the effectiveness of tofu, oncom and peanut attractants on fly traps in controlling flies in the Kalirejo Market area, Central Lampung Regency. Methods: This study uses a true experiment design with a posttest control group design. The population in this study were all types of flies in the Kalirejo Market. The sample in this study were flies caught in fly traps. Data analysis was univariate and bivariate with One Way Anova method for data with normal distribution and Kruskal-Wallis for data with abnormal distribution. Results: The use of peanut attractants was able to catch flies with an average of 21.11 flies caught, 15.39 tails on oncom attractants, 4.89 on tofu attractants ( $p$ value $<0.05$ ). The temperature conditions at the time of the study were $260 \mathrm{C}$ to $270 \mathrm{C}$ with a humidity percentage of $68 \%$ to $70 \%$. Conclusion: from this study, there were differences in the average number of flies caught in the use of tofu, oncom and peanut attractants.
\end{abstract}




\section{Pendahuluan}

Tindakan pengendalian lalat bertujuan untuk mengurangi atau melenyapkan gangguan yang ditimbulkan oleh lalat [1]. Keberadaan lalat dapat mengganggu masyarakat karena sebagai salah satu vektor perantara penyebaran penyakit berbasis lingkungan [1,2]. Proses penyebaran penyakit yang disebabkan oleh lalat disebarkan secara mekanik, oleh bakteri yang menempel pada kaki dan bagian tubuh lalat yang kemudian tertinggal di tempat yang disinggahi lalat. Penyakit yang dapat ditularkan oleh lalat berupa infeksi saluran pencernaan, disentri, diare, tifoid, kolera dan infeksi cacing [3]. Faktor-faktor yang mempengaruhi keberadaan lalat yaitu makanan lalat, sanitasi, suhu dan kelembaban. Kebiasaan makan lalat bertujuan untuk bertahan hidup, lalat menyukai makanan yang bercita rasa manis seperti gula dan susu, memiliki kandungan protein yang tinggi seperti ikan, daging, tempe, tahu, oncom bahkan kacang tanah [4]. Keberadaan lalat juga dipengaruhi oleh kelembaban dan suhu. Lalat bertahan pada suhu 280C hingga 320C lalat akan beraktivitas secara maksimal. Suhu kurang dari 160C dan lebih dari 480C aktivitas lalat akan berkurang [5]. Tempat-tempat yang berhubungan dengan keberadaan manusia seperti permukiman penduduk, tempat-tempat umum (pasar, tempat pemotongan ayam, peternakan ayam, warung makan), TPS dan TPA diperlukan pengendalian lalat $[6,7]$.

Pasar Tradisional Kalirejo merupakan pasar yang terletak di pusat Kecamatan Kalirejo. Pasar kalirejo beroperasi setiap hari, namun untuk penjualan bahan makanan hanya tersedia di hari senin, kamis dan sabtu. Setiap harinya pasar ini akan menghasilkan limbah, yang berupa tumpukan sampah organik dari sisa buah-buahan dan sisa sayur-sayuran. Hal ini dapat menjadi faktor yang mempengaruhi keberadaan lalat. Menurut Permenkes Nomor 374/Menkes/PER/2010 tentang pengendalian vektor. Kegiatan pengendalian vektor penyakit bertujuan untuk memutuskan rantai penularan penyakit, dan mengendalikan penyakit tular vektor sampai ketingkat yang tidak membahayakan bagi kesehatan manusia [1]. Upaya pengendalian lalat menggunakan bahan kimia dapat menurunkan populasi vektor dengan segera, akan tetapi penggunaan bahan kimia tidak cukup aman apabila digunakan berlebihan dikarenakan dapat menurunkan kualitas lingkungan $[8,9]$.

Salah satunya dengan menggunakan perangkap lalat (fly trap), screening dan electrocution. Salah satu yang paling umum digunakan yaitu fly trap. Cara ini berguna untuk mengendalikan jumlah populasi lalat dengan menggunakan fly trap yang dapat dimodifikasi dan ditambah dengan penggunaan atraktan sebagai pemikat ataupun penarik lalat $[9,10]$. Penggunaan atraktan dapat dimodifikasi dengan makanan yang disukai lalat, seperti makanan yang dimakan manusia memiliki rasa manis, mengandung protein yang tinggi seperti kacang tanah, serta memiliki aroma yang tajam (busuk) [11, 12]. Selain menyukai makanan yang tinggi akan protein seperti kacang tanah, tahu dan oncom. Hal ini sebagai atraktan dengan inovasi baru dalam mengendalikan jumlah lalat menggunakan media fly trap [13]. Tahu, oncom dan kacang tanah merupakan makanan yang paling mudah didapatkan di Pasar Kalirejo, berdasarkan survey awal, terdapat lebih dari 3 penjual tahu, oncom dan kacang tanah. Sebelum tahu dan oncom menjadi atraktan pada fly trap, tahu dan oncom akan didiamkan selama 4 hari untuk menajamkan aroma dari tahu dan oncom. Sedangkan kacang tanah akan disangrai terlebih dahulu kemudian dihaluskan dengan penggiling manual. Berat dari masing-masing atraktan yaitu 50 gr.

Lalat merupakan serangga yang menyukai sinar atau serangga yang fototropik, maka diciptakan sebuah fly trap dengan atraktan sebagai umpan penarik yang diletakkan dibawah perangkap yang dindingnya terbuat dari kain strimin, supaya setelah lalat memakan atraktan kemudian terbang menuju arah asal cahaya yang dinding ruangan terangnya telah tertutup oleh kain strimin, disinilah lalat tertangkap di dalam fly trap $[9,14]$. Penelitian yang telah dilakukan oleh Robson dan Oemry, penggunaan tempe dan kakao sebagai umpan. Eksperimen tersebut menyimpulkan tempe dianggap paling efektif karena mengandung protein hidrolisat. Kegiatan eksperimen tersebut diperoleh jumlah populasi lalat buah yang tertangkap terbesar pada minggu empat sebesar 155 ekor. Limbah kakao memerangkap lalat dengan rata-rata sebanyak 12,33 ekor pada minggu pertama sampai minggu ke empat, sedangkan limbah tempe memerangkap lalat dengan rata-rata 8,67 ekor [15]. Pengendalian lalat dapat dilakukan dengan menggunakan atraktan yang dipasang pada fly trap. Atraktan dimodifikasi oleh tahu, oncom dan kacang tanah. Berdasarkan uraian tersebut, penelitian ini bertujuan untuk menganalisa efektivitas atraktan tahu, oncom dan kacang tanah pada fly trap dalam pengendalian lalat.

\section{Metode}

Penelitian ini menggunakan metode True Experiment termasuk jenis penelitian kuantitatif. Penelitian ini dilakukan di Pasar Kalirejo, Kabupaten Lampung Tengah, Lampung pada bulan Desember 2020 - Januari 2021. Populasi penelitian ini adalah semua lalat yang berada di area Pasar Kalirejo. Sampel dalam penelitian ini adalah semua jenis lalat yang tertangkap pada fly trap dengan tahu, oncom dan kacang tanah dan 
fly trap tanpa tambahan atraktan sebagai kontrol. Teknik penarikan sampel berdasarkan pengulangan dengan rumus $(\mathrm{t}-1)(\mathrm{n}-1) \geq 15,5)$ sehingga didapatkan pengulangan akan dilakukan sebanyak 6 kali [16]. Alat dan bahan pada penelitian ini adalah fly trap, atraktan, counter, stopwatch dan alat tulis. Fly trap terbuat dari rangka kubus berbahan kayu dengan ukuran $30 \mathrm{~cm} 2$ yang dilapisi oleh kain strimin. Atraktkan tahu dan oncom dibusukkan dengan cara didiamkan selama 4 hari disuhu ruang dalam kondisi wadah tertutup untuk menajamkan aromanya, sedangkan pada kacang tanah untuk mendapatkan aroma yang tajam perlu dilakukan penyangraian kemudianketiga atraktan tersebut dihaluskan dan diletakkan di 3 wadah berbeda untuk ditempatkan dibawah fly trap. Fly trap diletakkan pada titik yang telah ditentukan dengan jarak 1 meter antar fly trap dan dibiarkan selama 1 jam lalu di hitung jumlah lalat yang tertangkap pada masing-masing jenis atraktan. Data jumlah lalat yang tertangkap dicatat pada tabel distribusi frekuensi. Data yang diperoleh dari penelitian dilakukan analisa univariat adalah analisis yang dilakukan untuk menggambarkan distribusi dan frekuensi variabel penelitian yang akan dijadikan dalam bentuk tabel dan diinterpretasikan dalam bentuk teks. Analisis bivariat yaitu analisis yang dilakukan untuk membuktikan ada atau tidak efektivitas antara variabel bebas dengan variabel terikat. Uji yang digunakan adalah uji One Way ANOVA. Jika $\mathrm{p}$ value $\leq 0,05$ membuktikan ada pengaruh jenis atraktan yang paling disukai lalat dan jika $\mathrm{p}$ value $>0,05$, maka tidak ada pengaruh jenis atraktan yang paling disukai lalat.

\section{Hasil}

Sebelum meletakan fly trap di 3 titik pengukuran, dilakukan dilakukan pengukuran suhu dan kelembaban menggunakan thermohygrometer.

Tabel 1. Hasil Pengukuran Suhu dan Kelembaban

\begin{tabular}{lll}
\hline $\begin{array}{l}\text { Titik } \\
\text { Pengukuran }\end{array}$ & $\begin{array}{l}\text { Hasil } \\
\text { Pengukuran } \\
\text { Suhu }\end{array}$ & $\begin{array}{l}\text { Hasil } \\
\text { Pengukuran } \\
\text { Kelembaban }\end{array}$ \\
\hline 1 & $26,8^{0} \mathrm{C}$ & $68,30 \%$ \\
\hline 2 & $27^{0} \mathrm{C}$ & $68 \%$ \\
\hline 3 & $26,5^{0} \mathrm{C}$ & $69 \%$ \\
\hline
\end{tabular}

Dilanjutkan dengan penempatan 4 fly trap dengan 3 atraktan (tahu, oncom dan kacang tanah) dan 1 tanpa atraktan sebagai kontrol. Tersaji pada tabel 2 Distribusi frekuensi lalat yang tertangkap pada tiap atraktan pada fly trap.

Tabel 2 Distribusi Frekuensi Lalat Yang Tertangkap

\begin{tabular}{lccccc}
\hline \multicolumn{1}{c}{ Variabel } & Mean & Sd & Varians & Min & Mak \\
\hline Jumlah Lalat Pada Atraktan Tahu & 5,89 & 1,491 & 2,222 & 3 & 8 \\
Jumlah Lalat Pada Atraktan Oncom & 15,39 & 3,146 & 9,899 & 11 & 22 \\
& & & & & \\
& 21,11 & 4,418 & 18,516 & 14 & 27 \\
Jumlah Lalat Pada Atraktan Kacang Tanah & 1,94 & 0,998 & 0,997 & 0 & 4 \\
Jumlah Lalat Tanpa Atraktan (Kontrol) & & &
\end{tabular}

Berdasarkan tabel 2 didapatkan bahwa fly trap tanpa atraktan (kontrol) menangkap lalat paling sedikit. Rata-rata jumlah lalat yang tertangkap pada fly trap tanpa atraktan (kontrol) sebanyak 1,94. Fly trap yang menggunakan atraktan, rata-rata jumlah lalat yang tertangkap paling sedikit yaitu pada atraktan tahu. Atraktan tahu rata-rata lalat yang tertangkap sebesar
5,89. Selanjutnya rata-rata jumlah lalat yang tertangkap paling banyak yaitu pada atraktan kacang tanah. Atraktan kacang tanah tertangkap sebesar 21,11. Sedangkan pada atraktan oncom rata-rata jumlah lalat yang tertangkap tidak sebanyak rata-rata yang tertangkap pada atraktan kacang tanah, namun tidak sesedikit pada atraktan tahu. Rata-rata jumlah lalat yang tertangkap pada atraktan kacang tanah sebesar 15,39.

Tabel 3. Jumlah Lalat Yang Tertankap Berdasarkan Atraktan Yang Digunakan

\begin{tabular}{|c|c|c|c|c|}
\hline & Variasi Atraktan & $\mathrm{N}$ & $\begin{array}{c}\text { Rerata (s.b) ekor/ } \\
\text { Fly Trap }\end{array}$ & $P$-Value \\
\hline \multirow{4}{*}{ Jumlah Lalat } & Tahu & 18 & $4,82(1,49)$ & \multirow{4}{*}{0,000} \\
\hline & Oncom & 18 & $15,27(3,14)$ & \\
\hline & Kacang Tanah & 18 & $18,91(4,41)$ & \\
\hline & Kontrol & 18 & $1,94(0,99)$ & \\
\hline
\end{tabular}


Berdasarkan tabel 3 secara statistik nilai significancy test of homogeneity of variances menunjukkan angka 0,000 ( $\mathrm{p}-$ value < 0,05) oleh karena itu, maka dapat ditarik kesimpulan bahwa paling tidak terdapat dua kelompok yang mempunyai varians yang berbeda. Nilai significancy ANOVA menunjukkan angka $0,000 \mathrm{p}$ - value $<0,05$ ) sehingga kesimpulannya tolak H0 yang berarti ada perbedaan jumlah lalat yang tertangkap dengan atraktan tahu, atraktan oncom dan atraktan kacang tanah. Uji One way Anova bermakna dan varian berbeda sehingga untuk mengetahui perbedaan antar kelompok maka dilakukan analisis pos hoc Tamhane"s pada tabel 3. Berdasarkan Tabel 4, perbedaan rata-rata terbesar jumlah lalat yang tertangkap pada atraktan kacang tanah terhadap kontrol yaitu sebesar 19,16 dengan p-value 0,000 <0,05.

Tabel 4. Hasil Uji Pos Hoc Tamhane's Terhadap Lalat Yang Tertangkap Pada Berbagai Atraktan Yang Digunakan

\begin{tabular}{lcrrr}
\hline & Perbedaan & \multicolumn{2}{c}{$95 \%$ CI } & \multirow{2}{*}{-value } \\
\cline { 2 - 4 } & Rata-rata & Minimum & Maksimum & \\
\hline Oncom vs Tahu & 10,50 & 8,15 & 12,85 & 0,00 \\
Kacang tanah vs Tahu & 16,22 & 13,03 & 19,41 & 0,00 \\
Tahu vs Kontrol & 2,944 & 1,75 & 4,14 & 0,00 \\
Oncom vs Kontrol & 13,44 & 11,18 & 15,71 & 0,00 \\
Kacang Tanah vs Kontrol & 19,16 & 16,03 & 22,30 & 0,00 \\
Oncom vs Kacang Tanah & 5,72 & 2,13 & 9,32 & 0,01 \\
\hline
\end{tabular}

\section{Pembahasan}

Atraktan merupakan bahan yang dapat digunakan untuk mendatangkan serangga agar masuk kedalam perangkap yang dipasang. Penggunaan atraktan dalam pengendalian lalat juga dapat dilakukan secara kimiawi dan fisik [1, 17]. Atraktan dari bahan kimia dapat berupa senyawa ammonia, CO2, asam laktat, etanol, dan asam lemak [18]. Atraktan fisik dapat dilakukan dengan penggunaan makanan atau food attraktant yang disukai oleh lalat yang memiliki kandungan protein dan memiliki kandungan kadar air yang relative sedikit. Pengggunaan food attraktant atau bahan makanan sebagai penarik difokuskan pada bahan makanan yang disukai oleh lalat, sehingga dapat memaksimalkan tujuan penggunaannya yang akan digunakan untuk menarik atau mendekatkan serangga dan kemudian masuk ke dalam perangkap [19]. Berdasarkan hasil penelitian dapat dilihat bahwa ratarata jumlah lalat tertangkap paling banyak pada atraktan kacang tanah. Rata-rata jumlah lalat yang tertangkap sebanyak 21,11 ekor. Sedangkan pada atraktan lainnya seperti tahu, rata-rata jumlah lalat yang tertangkap sebanyak 5,89 ekor. Atraktan oncom, rata-rata jumlah lalat yang tertangkap sebanyak 15,39 ekor dan fly trap tanpa atraktan (kontrol) rata-rata jumlah lalat yang tertangkap sebanyak 1,94 ekor.

Berdasarkan paparan data tersebut, rata-rata jumlah lalat tertangkap pada fly trap dengan perlakuan atraktan (tahu, oncom dan kacang tanah) yang paling banyak menangkap lalat adalah atraktan kacang tanah. Kacang tanah memiliki kandungan asam lemak dan protein yang paling tinggi diantara atraktan tahu dan oncom. Asam lemak dan protein merupakan kandungan pada makanan yang disukai oleh lalat untuk meletakkan telur-telurnya. Kacang tanah mengandung 40\%-50\%, protein 20\%-30\% dan mineral. Kacang tanah memiliki kandungan protein dan asam lemak lebih tinggi dibandingkan dengan atraktan tahu yang mengandung $8 \%$ protein dan $4 \%-5 \%$ asam lemak dan atraktan oncom yang mengandung protein $13 \%-15 \%$ [20, 21].

Lalat lebih tertarik hinggap pada atraktan kacang tanah dibandingkan atraktan oncom dan atraktan tahu. Rata-rata jumlah lalat yang tertangkap pada atraktan oncom lebih tinggi daripada atraktan tahu, selain kandungan protein dan asam lemak pada oncom yang lebih tinggi, setelah proses pembusukan oncom dan tahu selama 4 hari, atraktan oncom mengeluarkan aroma ammonia yang tebih tajam dari atraktan tahu sehingga lalat lebih tertarik hinggap pada atraktan oncom dibandingkan atraktan tahu. Hasil penelitian ini sejalan dengan penelitian yang telah dilakukan oleh Putra dan Kermelita bahwa penggunaan atraktan yang memiliki tekstur kering dan mengandung protein yang tinggi dapat mempengaruhi jumlah lalat yang tertangkap pada fly trap. memodifikasi tempe, ikan dan sampah organik sebagai atraktan [18].

Penggunaan atraktan yang paling banyak menangkap lalat yaitu atraktan tempe. Berdasarkan ratarata jumlah lalat yang tertangkap, sebanyaak 152 lalat tertangkap pada atraktan sampah organik, 240 lalat tertangkap pada atraktan ikan, dan 331 lalat tertangkap pada atraktan tempe. Penelitian tersebut menyebutkan 
bahwa protein merupakan makanan kesukaan lalat dan sering digunakan oleh lalat untuk meletakan telurnya. Selain itu atraktan yang memili kandungan kadar air lebih sedikit akan lebih menarik lalat.

Penggunaan atraktan yang tinggi protein seperti kacang tanah, oncom dan tahu dapat dilakukan untuk memerangkap lalat pada fly trap. Ketiga atraktan tersebut mudah diperoleh di pasar tradisional atau tempat penjualan bumbu dapur. Atraktan kacang tanah tidak berbahaya bagi lingkungan sekitar ataupun manusia karena tidak mengandung bahan kimia yang berbahaya [22]. Penggunaan kacang tanah untuk atraktan dapat dilakukan dengan cara menyangrai kacang tanah kemudian dihaluskan. Sedangkan untuk tahu dan oncom perlu didiamkan selama 4 hari terlebih dahulu kemudian dicincang kasar atau dihaluskan, proses mendiamkan tahu dan oncom bertujuan untuk mengeluarkan aroma yang dapat mengundang lalat.

Lalat juga dapat dipengaruhi oleh faktor lingkungan seperti suhu dan kelembaban [7, 23]. Titik pertama dengan rata-rata suhu $26,8^{\circ} \mathrm{C}$ diperoleh ratarata lalat yang tertangkap pada fly trap dengan atraktan tahu sebanyak 4,83, rata-rata lalat pada atraktan oncom sebanyak 13,67, rata-rata lalat pada atraktan kacang tanah sebanyak 16,17 dan fly trap tanpa atraktan sebanyak 1,5. Pada titik kedua dengan rata-rata suhu $27^{\circ} \mathrm{C}$ diperoleh rata-rata lalat yang tertangkap pada fly trap dengan atraktan tahu sebanyak 5,67, rata-rata lalat pada atraktan oncom sebanyak 18,67 , rata-rata lalat pada atraktan kacang tanah sebanyak 25,67 dan fly trap tanpa atraktan sebanyak 2,17 . Selanjutnya pada titik ketiga dengan suhu rata-rata $26,5^{\circ} \mathrm{C}$ diperoleh rata-rata lalat yang tertangkap pada fly trap dengan atraktan tahu sebanyak 4,17, rata-rata lalat pada atraktan oncom sebanyak 13,83, rata-rata lalat pada atraktan kacang tanah sebanyak 21,50 dan fly trap tanpa atraktan sebanyak 2,17.

Tidak signifikan yang menunjukan bahwa tidak terdapat hubungan antara suhu dan kepadatan lalat diluar rumah dan didalam rumah [6]. Namun, penelitian ini bertentangan dengan penelitian yang dilakukan oleh Ramadhani dan Hestiningsih secara statistic terdapat hubungan yang signifikan antara suhu dengan kepadatan lalat di desa Purwodadi [4].

Aktivitas lalat secara optimum akan beraktivitas pada kelembaban $90 \%$ [24]. Titik pertama dengan kelembaban rata-rata 68,3\% diperoleh rata-rata lalat yang tertangkap pada fly trap dengan atraktan tahu sebanyak 4,83, rata-rata lalat pada atraktan oncom sebanyak 13,67, rata-rata lalat pada atraktan kacang tanah sebanyak 16,17 dan fly trap tanpa atraktan sebanyak 1,5. Titik kedua dengan kelembaban rata-rata
$68 \%$ diperoleh rata-rata lalat yang tertangkap pada fly trap dengan atraktan tahu sebanyak 5,67, rata-rata lalat pada atraktan oncom sebanyak 18,67, rata-rata lalat pada atraktan kacang tanah sebanyak 25,67 dan fly trap tanpa atraktan sebanyak 2,17. Selanjutnya pada titik ketiga dengan kelembaban rata-rata 69\% diperoleh ratarata lalat yang tertangkap pada fly trap dengan atraktan tahu sebanyak 4,17, rata-rata lalat pada atraktan oncom sebanyak 13,83, rata-rata lalat pada atraktan kacang tanah sebanyak 21,50 dan fly trap tanpa atraktan sebanyak 2,17.

Tidak terdapat hubungan yang signifikan antara kelembaban dengan kepadatan lalat di desa purwodadi [4]. Penelitian tersebut menyatakan bahwa kelembaban akan berpengaruh dengan kondisi suhu. Semakin tinggi suhu, maka presentase kelembaban akan semakin menurun sehingga aktivitas lalat akan berkurang. Kepadatan lalat sangat dipengaruhi oleh kelembaban udara. Kelembaban udara yang optimal untuk disukai lalat pada rentang 45\% - 90\% karena sesuai dengan kebutuhan hidup lalat [25].

\section{Kesimpulan}

Berdasarkan hasil penelitian yang telah dilakukan, terdapat perbedaan bermakna pada distribusi frekuensi lalat yang tertangkap pada atraktan tahu, oncom dan kacang tanah $p$ value $(0,00)<\alpha(0,05)$. Atraktan yang paling baik dalam memperoleh jumlah lalat yang tertangkap yaitu atraktan kacang tanah, dengan rata-rata lalat yang tertangkap pada atraktan kacang tanah sebesar 21,11 ekor sedangkan rata-rata lalat yang tertangkap pada atraktan tahu sebesar 5,89 ekor dan rata-rata lalat yang tertangkap pada atraktan oncom sebesar 15,39 ekor. Penggunaan atraktan dapat dimodifikasi dengan yang disukai lalat seperti atraktan yang memiliki kandungan protein yang tinggi serta dengan harga yang murah. Namun untuk mengendalikan lalat secara maksimal dapat disertai denngan upaya perbaikan sanitasi.

\section{Ucapan Terimakasih}

Terimakasih kepada Fakultas Kesehatan Masyarakat yang telah memfasilitasi penelitian ini.

\section{Daftar Pustaka}

[1] Peraturan Menteri Kesehatan Nomor 374/Menkes/Per/III/2010, 2010.

[2] C. D. Sucipto, Vektor penyakit tropis. Yogyakarta: Gosyen Publishing, 2011.

[3] D. Wahyuni, Makomulamin, and N. P. Sari, Entomologi Dan Pengendalian Vektor. Yogyakarta: CV Budi Utamaa, 2017. 
[4] C. Ramadhani, R. Hestiningsih, and N. Kusariana, "Faktor-Faktor yang berhubungan dengan kepadatan lalat di desa purwodadi kecamatan margoyoso kabupaten pati," Jurnal Kesehatan Masyarakat (e-Journal), vol. 7, pp. 29-38, 2019.

[5] I. M. Ihsan, "Pengaruh Suhu Udara terhadap Perkembangan Pradewasa Lalat Rumah (Musca domestica)," Jurnal Teknologi Lingkungan, vol. 17, pp. 100-107, 2016.

[6] E. N. Afrilia and B. Wispriyono, "Hubungan Kondisi Rumah dan Kepadatan Lalat di sekitar Tempat Pembuang Akhir Sampah," jurnal Fakultas Kesehatan Masyarat, vol. 11, 2017.

[7] M. Masyhuda, R. Hestiningsih, and R. Rahadian, "Survei Kepadatan Lalat Di Tempat Pembuangan Akhir (TPA) Sampah Jatibarang Tahun 2017," Jurnal Kesehatan Masyarakat (e-Journal), vol. 5, pp. 560-569, 2017.

[8] E. S. M. Nadeak, T. Rwanda, and I. Iskandar, "Efektifitas Variasi Umpan Dalam Penggunaan Fly Trap Di Tempat Pembuangan Akhir Ganet Kota Tanjungpinang," Jurnal Kesehatan Masyarakat Andalas, vol. 10, pp. 82-86, 2017.

[9] N. Tanjung, "Efektifitas Berbagai Bentuk Fly Trap Dan Umpan Dalam Pengendalian Kepadatan Lalat Pada Pembuangan Sampah Jalan Budi Luhur Medan Tahun 2016," 2017.

[10] D. Mustikawati, M. Martini, and M. Hadi, "Pengaruh Variasi Umpan Aroma terhadap Jumlah Lalat yang Terperangkap dalam Perangkap Warna Kuning (Studi di Kandang Sapi Dusun Tegalsari Desa Sidomukti Kecamatan Bandungan Kabupaten Semarang)," Jurnal Kesehatan Masyarakat (Undip), vol. 4, pp. 275-281, 2016.

[11] R. Margareta and W. H. Cahyati, "Efektivitas Fly Trap Terhadap Musca Domestica," VISIKES: Jurnal Kesehatan Masyarakat, vol. 19, 2020.

[12] S. D. R. Siska Desti Rahayu, "Efektivitas Variasi Limbah Buah Sebagai Atraktan Pada Eco-Friendly Fly Trap Terhadap Jumlah Dan Jenis Lalat Terperangkap," Poltekkes Kemenkes Yogyakarta, 2019.

[13] S. Saipin, F. R. Fadmi, and A. Mauliyana, "Efektivitas Variasi Umpan Terhadap Penggunaan Perangkap Lalat (Fly Trap) Di
Pasar Basah Anduonohu Kota Kendari," MIRACLE Journal of Public Health, vol. 2, pp. 112-120, 2019.

[14] F. K. Putra, "Efektifitas Atraktan Pada Fly Trap Terhadap jumlah Lalat Rumah (Musca Domestica)," JURNAL MEDIA KESEHATAN, vol. 6, pp. 112-116, 2013.

[15] E. Robson and S. Oemry, "Ketertarikan Lalat Buah (Diptera: Teprhidate) pada Senyawa Atraktan yang Mengandung Protein dan Ketinggian Perangkap Berbeda pada Tanaman Jeruk: Attraction of Fruit Flies (Diptera: Teprhidate) on Atractants Containing Protein and Different Trap Height on Citrus Plants," Jurnal Online Agroekoteknologi, vol. 7, pp. 368-375, 2019.

[16] Sugiyono, Metode Penelitian Kuantitatif. Bandung: Alfabetha, 2018.

[17] Standar Operasional Prosedur Pengendalian Lalat, 2009.

[18] F. K. Putra, D. Kermelita, and Jubaidi, "Efektifitas Atraktan Pada Fly Trap Terhadap Jumlah Lalat Rumah (Musca Domestica)," Jurnal Media Kesehatan, vol. 6, 2013.

[19] O. D. Wulansari, S. E. Windarso, and N. Narto, "Pemanfaatan Limbah Nangka (Jerami) sebagai Atraktan Lalat pada Flytrap," Sanitasi: Jurnal Kesehatan Lingkungan, vol. 9, pp. 122127, 2018.

[20] N. Istinaroh, "Analisis Kadar Protein Pada Tahu Putih, Tahu Susu Dan Tahu Bulat," Universitas Muhammadiyah Jember, 2019.

[21] T. Zulchi and H. Puad, "Keragaman Morfologi dan Kandungan Protein Kacang Tanah (Arachis hypogaea L.)," 2018.

[22] S. Savitriani and N. A. Maftukhah, "Efektivitas Variasi Umpan Pada Fly Trap Dalam Pengendalian Kepadatan Lalat," Ruwa Jurai: Jurnal Kesehatan Lingkungan, vol. 15, pp. 1622, 2021.

[23] Z. Malinda, "Gambaran Kepadatan Lalat Di Pasar Wonokromo Tahun 2020," Poltekkes Kemenkes Surabaya, 2020.

[24] A. Subagyo, A. Widyanto, and A. Santjaka, "Fly Density and Identification Analysis and Control Efforts In Traditional Market Purwokerto," Jurnal Riset Kesehatan, vol. 3, pp. 483-491, 2014.

[25] C. D. Sucipto, Kesehatan Lingkungan. Yogyakarta: Gosyen Publishing, 2019. 